\title{
Layoffs and Employer Branding: Empirical Study of SME in Xinjiang of China
}

Guo Bing, Asif Mahbub Karim, Lei Jianqiang

To Link this Article: http://dx.doi.org/10.6007/IJARBSS/v11-i1/8122

DOI:10.6007/IJARBSS/v11-i1/8122

Received: 25 November 2020, Revised: 20 December 2020, Accepted: 05 January 2021

Published Online: 21 January 2021

In-Text Citation: (Bing et al., 2021)

To Cite this Article: Bing, G., Karim, A. M., \& Jianqiang, L. (2021). Layoffs and Employer Branding: Empirical Study of SME in Xinjiang of China. International Journal of Academic Research in Business and Social Sciences, 11(1), 364-373.

\section{Copyright: (c) 2021 The Author(s)}

Published by Human Resource Management Academic Research Society (www.hrmars.com)

This article is published under the Creative Commons Attribution (CC BY 4.0) license. Anyone may reproduce, distribute, translate and create derivative works of this article (for both commercial and non-commercial purposes), subject to full attribution to the original publication and authors. The full terms of this license may be seen at: http://creativecommons.org/licences/by/4.0/legalcode

Vol. 11, No. 1, 2021, Pg. 364 - 373

Full Terms \& Conditions of access and use can be found at http://hrmars.com/index.php/pages/detail/publication-ethics 


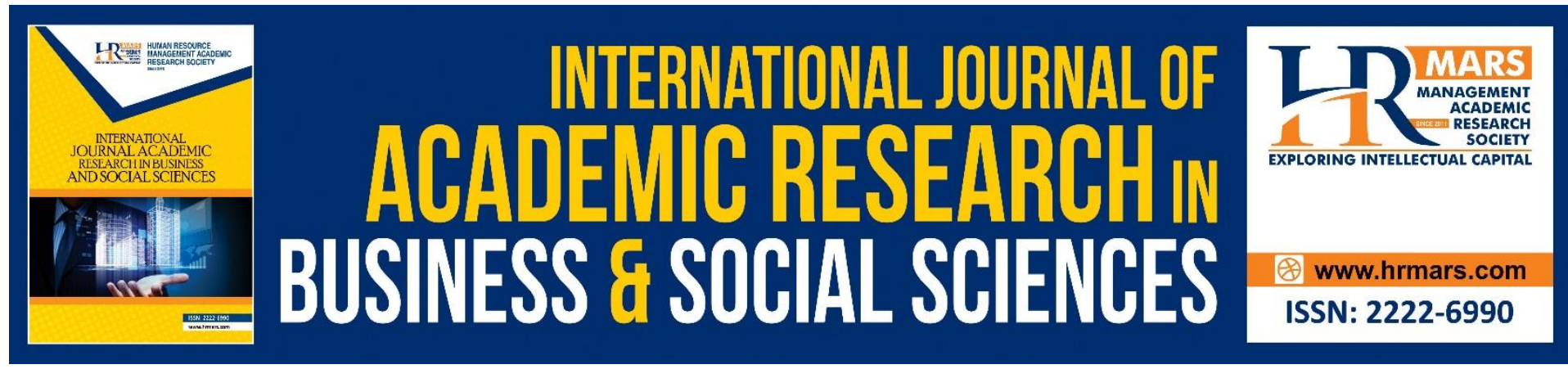

\title{
Layoffs and Employer Branding: Empirical Study of SME in Xinjiang of China
}

\author{
Guo Bing ${ }^{1}$, Dr. Asif Mahbub Karim², Lei Jianqiang ${ }^{3}$
}

${ }^{1} \mathrm{PhD}$ Research Fellow, Binary University of Management \& Entrepreneurship, Malaysia ${ }^{2}$ Dean \& Associate Professor, Binary Graduate School, Binary University of Management \&

Entrepreneurship, Malaysia, ${ }^{3} \mathrm{PhD}$ Candidate, Binary University of Management \& Entrepreneurship, Malaysia

\begin{abstract}
The impact of COVID-19 on all walks of life is very obvious and positive, especially for SME. The decline of business performance leads to the survival difficulties of enterprises.most of reports shows Many enterprises have to lay off staff and reduce operating costs. At present, the study on human resources management is mostly concentrated in comprehensive theories and cases, but the study on employer brand lacks empirical study.So what influence to enterprise employer brand by layoffs on SME?this study aim at examine the effect layoffs on employer branding. SPSS system is adopted utilizing study collected the population data 100 , sample size of 80 from SME in Xinjiang, Empirical study shows that layoffs have a positive effect on employer branding.
\end{abstract}

Keywords: Human Resource Management, Layoffs, Employer Branding, SME

\section{Introduction}

Under the influence of the COVID-19, the global economy has been affected to a certain extent. The Bank for International Settlements (BIS) issued a report stating that the negative impact on GDP brought about by various countries' banning measures may last for several quarters, rather than only the first half of this year as predicted by the market. Taking into account the spillover effect brought about by the suspension of economic activities, even in the fourth quarter of next year, the global GDP growth rate will be lower than the level before the outbreak. United Nations Secretary-General Guterres stated at the World Health Summit on October 25 that the COVID-19 has caused the disappearance of 500 million jobs worldwide and the global monthly economic loss is about 375 billion US dollars. The previous data report in June showed that in the second quarter of 2020, global working hours will be reduced by $14 \%$, which is equivalent to the loss of 400 million full-time jobs. For enterprises, especially small and medium-sized enterprises (SME), the impact is more direct and significant. Many enterprises have to adopt certain measures to relieve the pressure of survival, among which layoffs are a measure. Talent is the key to the survival of an enterprise. The construction and maintenance of the employer branding is to attract and retain talent. Many scholars have done more research on how employer branding attracts talents, but there is less research on the impact of layoffs on employer branding, and there is a lack of empirical research. 
Therefore, this article explores the impact of layoffs on the employer branding of SME, which can enrich the results of employer brand research and propose related solutions to help Xinjiang SME maintain their employer brands under the influence of the COVID-19.We selected employees of small and medium enterprises in Xinjiang, collected 80 pieces of data, and analyzed them through SPSS.

The concept of Employer Branding was first proposed in 1990 by Simon Barrow in his article "Employer Brand" co-authored with Tim Ambler. It is a brand concept. Application in the field of human resources. In the current literature, different scholars have done research and enrichment on employer brand from different angles.

Hewitt (2000) believes that the employer brand is a kind of employer's promise, which is about the work culture, environment and opportunities that employees can experience after joining the company. Lefkou (2001) believes that the employer brand is a kind of promise, and the employer's ability to deliver the promise determines its identity in the minds of potential talents. The latter will largely decide whether to join the company because of this definition. Existing employees will decide whether to stay or leave based on whether their expectations are met. Ruch (2001) believes that employer brand is the image or personality of an enterprise in the minds of its employees and potential talents. And explained, "Just as well-known consumer brands can make people trust, accept and even purchase willingness, employer brands can not only make existing employees feel proud and satisfied, but also make job seekers have a desire to learn more about the company. "

In China, Ding (2007) believe that employer brand is an important component of the core strategy of a company. It applies the concept of marketing to human resource management, targeting potential external employees and existing internal employees, and improving human resources Management, improve employee satisfaction, attract outstanding talents, enhance corporate competitiveness, and promote sustainable development of the company. Guo (2010) believes that the employer brand is to establish a good image and prestige in the minds of the company's future and existing employees so as to attract, motivate and retain talents. Zhu (2008) started from the three dimensions of "symbols", "relationships" and "resources" and gave a three-dimensional definition of employer brand. Symbolic dimension: Employer brand is a symbol and sign that embodies differentiated employment commitments; Relationship dimension: Employer brand is an employment experience that can enhance corporate image; Resource dimension: Employer brand is a management promotion tool that can add value to the enterprise.

At present, China's evaluation of employer brand is basically divided into external perspective and internal perspective. The external perspective evaluation mainly includes the following types: The "Best Employer" selection jointly initiated by Zhaolian Recruitment APP and Peking University Social Research Center. The first selection started in 2005 and was jointly launched by Zhaopin Recruitment, CCTV Economic Channel, and Peking University. Sponsored by 58 Recruitment Website, a leading recruitment company in China, the employer brand selection is jointly participated by the School of Labor Relations of Renmin University of China, and authoritative media and institutions in the core fields of the industry. Related selections by other industry associations and media organizations. The evaluation of internal perspective mainly comes from the internal employees of the enterprise.

However, both external and internal evaluations use indicators to evaluate the employer branding.

Robert Levering proposed "Levering's Best Workplace Model", which evaluates from the three dimensions of the relationship between employees and their bosses and management, 
the relationship between employees and their own work and the company, and the relationship between colleagues. Hewitt, a world-renowned HR management consulting company, proposed five components of an employer brand: talent image, boss or CEO image, management system, corporate culture environment, and citizen image. The CCTV China Annual Employer Survey mainly focuses on the current working conditions and feelings of individual employees. The selection of the Best Employer of ChinaHR.com puts forward the CBCD model, including four dimensions: career development, salary and benefits, brand strength, and company culture. Zhu (2008) proposed to evaluate the employer branding from the seven dimensions of leadership and management style, personal development, work itself, corporate strength, welfare system, salary system, and cooperative relationship.

Combining China's national conditions and the actual situation of local enterprises in Xinjiang, this article selects the questionnaires from scholars such as ZhuYongguo, and adds the question of "layoffs on the company's development during the epidemic" in the dimension of enterprise strength, and appropriately modifies the matching research theme.

\section{Study Objects}

Analyzes the impact of layoffs on employer branding from the perspective of internal employees.

\section{Study Hypothesis}

layoffs have a positive impact on the employer branding. When employees believe that layoffs during the epidemic are not good for the company's development, and it is not good for the company's employer branding.

\section{Methods}

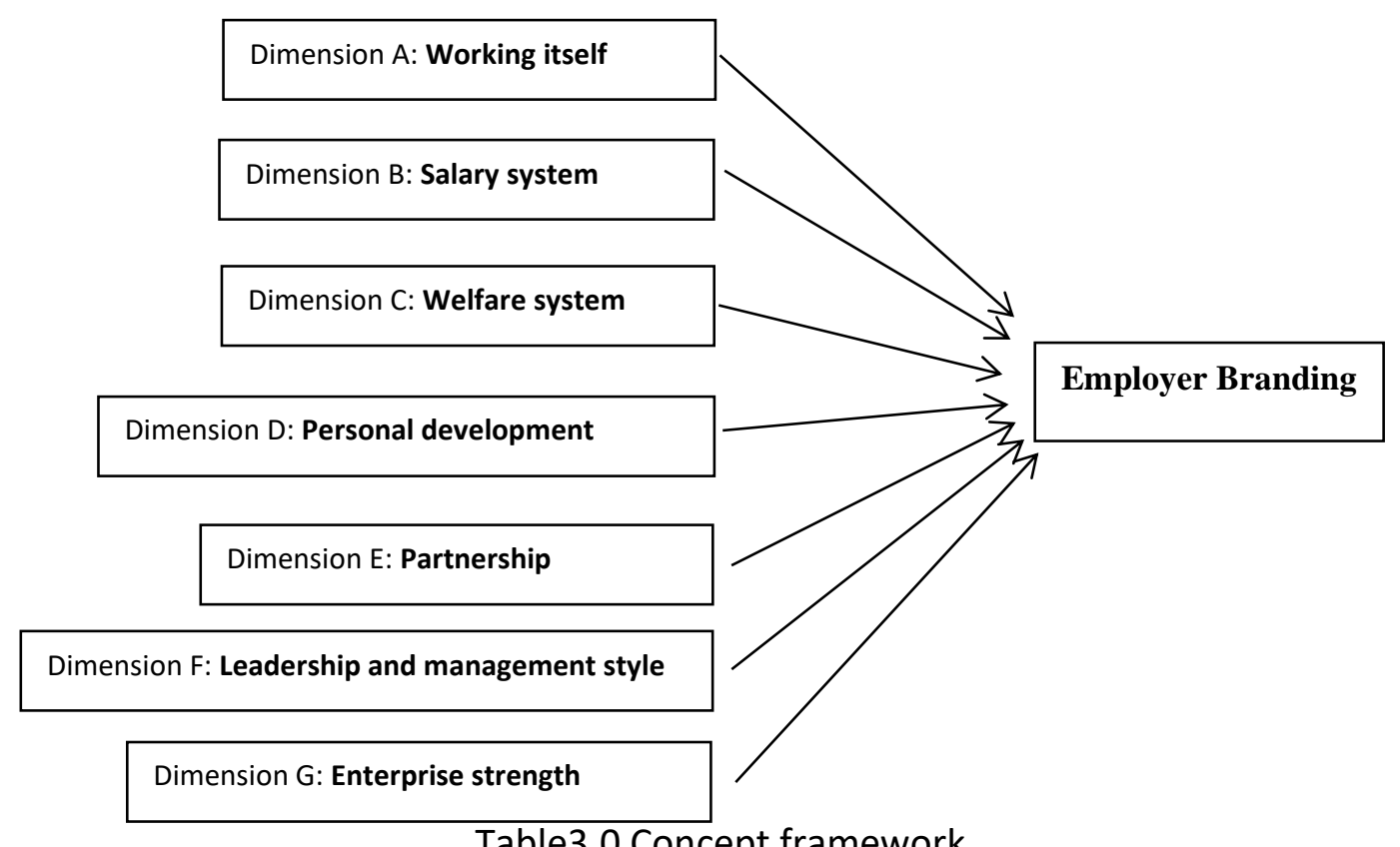

Table3.0 Concept framework

From the Table3.0 Concept framework,Dimension A-G are independent variables,and Employer Branding is dependent variable. 


\section{Sample Size}

This study selected 100 internal employees of small, medium and micro enterprises (SME) , Table 3.1 shows the required sample size was 80 , and the number of questionnaires returned was 80.SPSS system is adopted utilizing study collected the population data 100.

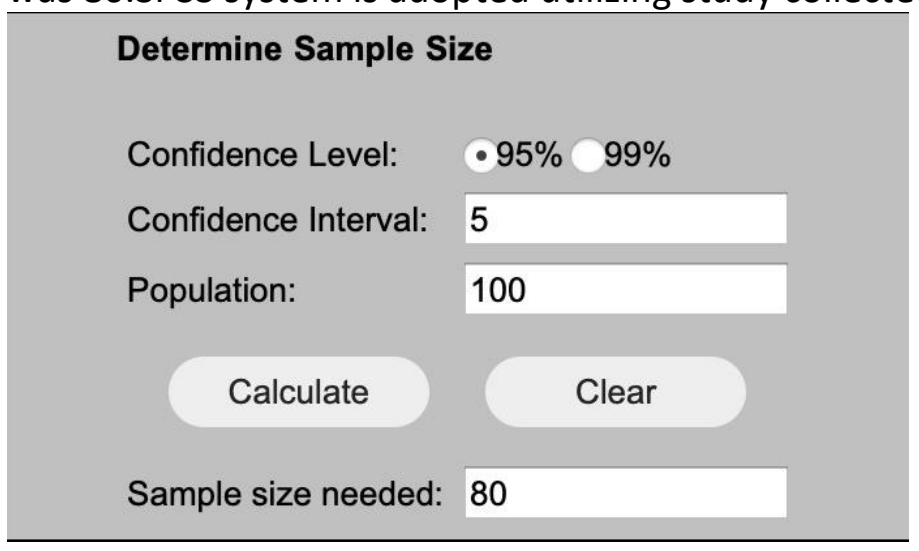

Table 3.1

\section{Sample Frequency Analysis}

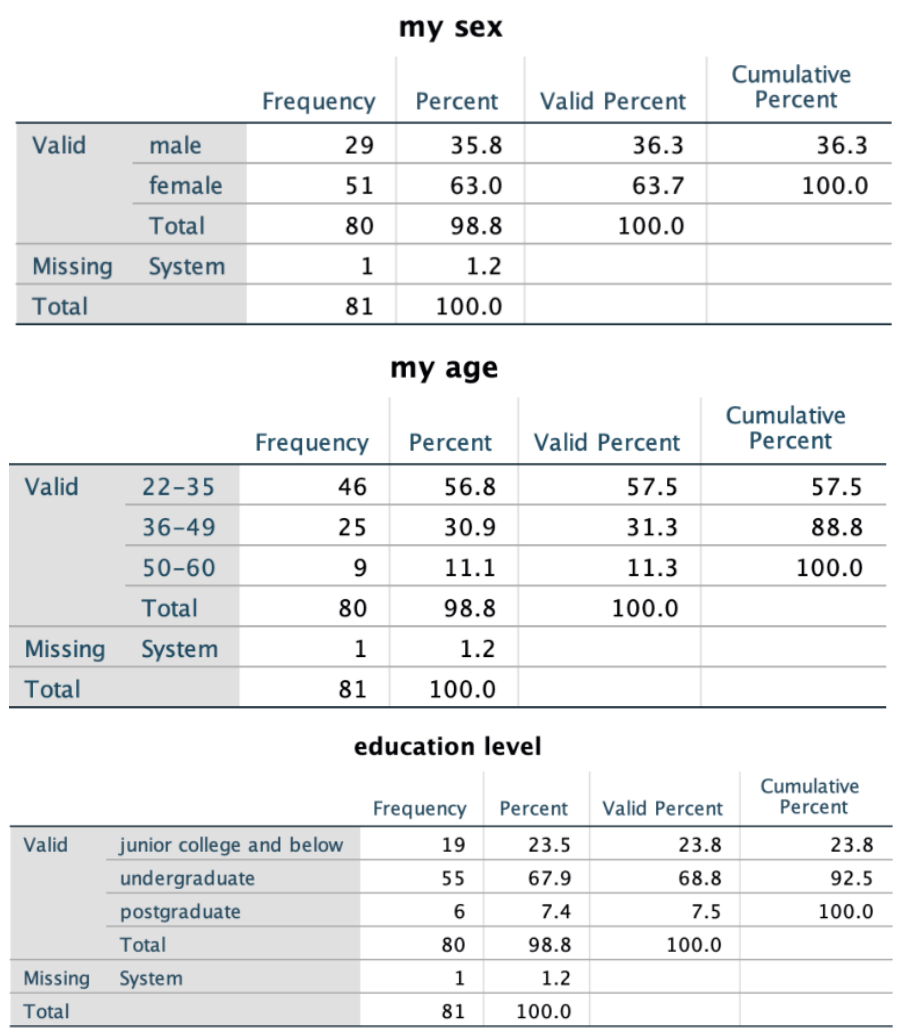

Table 3.2

From the Table3.2, In the 80 samples, male employees accounted for $35.8 \%$, with 29 employees, and female employees accounted for $63 \%$, with 51 employees. The number of employees aged 22-35 accounted for $56.8 \%$, the number was 46 , the number of employees aged $36-49$ accounted for $30.9 \%$, the number was 25 , and the number of employees aged $50-$ 60 accounted for $11.1 \%$. 9 people. The number of employees with college degree and below accounted for $23.5 \%$, and the number was 19 . The number of undergraduates accounted for 
$67.9 \%$, and the number was 55 . The number of employees with a degree in the laboratory accounted for $7.4 \%$, and the number was 6 .

Comprehensive analysis, this sample size has a bachelor's degree, and there are more people aged 22-35. This part of the population is the main force in the workplace.

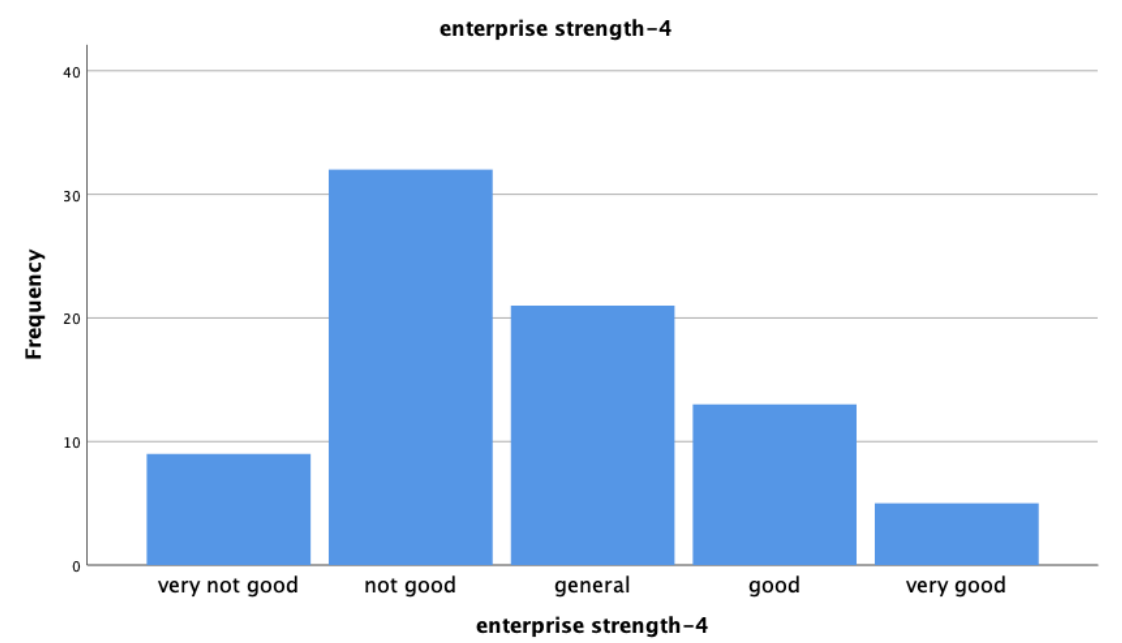

Table 3.3.1

\begin{tabular}{|c|c|c|c|c|c|}
\hline \multicolumn{6}{|c|}{ enterprise strength-4 } \\
\hline & & Frequency & Percent & Valid Percent & $\begin{array}{c}\text { Cumulative } \\
\text { Percent }\end{array}$ \\
\hline \multirow[t]{6}{*}{ Valid } & very not good & 9 & 11.1 & 11.3 & 11.3 \\
\hline & not good & 32 & 39.5 & 40.0 & 51.2 \\
\hline & general & 21 & 25.9 & 26.3 & 77.5 \\
\hline & good & 13 & 16.0 & 16.3 & 93.8 \\
\hline & very good & 5 & 6.2 & 6.3 & 100.0 \\
\hline & Total & 80 & 98.8 & 100.0 & \\
\hline Missing & System & 1 & 1.2 & & \\
\hline Total & & 81 & 100.0 & & \\
\hline
\end{tabular}

Table 3.3.2

Table 3.3.1and 3.1.2 shows among Dimension G NO.4 question data, the specific question is I think the layoffs during the epidemic period are the evaluation of the company's development. 39.5\% staff believe that not good.

\section{Reliability Analysis}

\section{Reliability Statistics}

\begin{tabular}{r|r}
$\begin{array}{c}\text { Cronbach's } \\
\text { Alpha }\end{array}$ & N of Items \\
\hline .957 & 36 \\
\hline
\end{tabular}

Table 3.4

Table3.4 shows the Alpha coefficient of all data in this study is 0.957 , which has passed the reliability test, indicating that the reliability of the questionnaire data is reliable. 


\section{Validity Analysis}

\section{KMO and Bartlett's Test}

\begin{tabular}{|c|c|c|}
\hline \multicolumn{2}{|c|}{$\begin{array}{l}\text { Kaiser-Meyer-Olkin Measure of Sampling } \\
\text { Adequacy. }\end{array}$} & .824 \\
\hline \multirow{3}{*}{$\begin{array}{l}\text { Bartlett's Test of } \\
\text { Sphericity }\end{array}$} & Approx. Chi-Square & 2479.466 \\
\hline & $\mathrm{df}$ & 630 \\
\hline & Sig. & .000 \\
\hline
\end{tabular}

Table 3.5

From Table3.5, the result of exploratory factor analysis showed that the KMO value was 0.824 , and it passed the Bartlett sphere test.

Total Variance Explained

\begin{tabular}{|c|c|c|c|c|c|}
\hline \multirow[b]{2}{*}{ Component } & \multicolumn{3}{|c|}{ Initial Eigenvalues } & \multicolumn{2}{|c|}{ Extraction Sums of Squared. } \\
\hline & Total & $\%$ of Variance & Cumulative \% & Total & $\%$ of Variance \\
\hline 1 & 16.181 & 44.947 & 44.947 & 16.181 & 44.947 \\
\hline 2 & 2.290 & 6.362 & 51.309 & 2.290 & 6.362 \\
\hline 3 & 1.710 & 4.749 & 56.058 & 1.710 & 4.749 \\
\hline 4 & 1.666 & 4.627 & 60.685 & 1.666 & 4.627 \\
\hline 5 & 1.502 & 4.172 & 64.857 & 1.502 & 4.172 \\
\hline 6 & 1.373 & 3.815 & 68.672 & 1.373 & 3.815 \\
\hline 7 & 1.229 & 3.413 & 72.085 & 1.229 & 3.413 \\
\hline 8 & 1.133 & 3.148 & 75.233 & 1.133 & 3.148 \\
\hline 9 & .878 & 2.440 & 77.673 & & \\
\hline 10 & .816 & 2.267 & 79.940 & & \\
\hline 11 & .736 & 2.046 & 81.986 & & \\
\hline 12 & .672 & 1.868 & 83.854 & & \\
\hline 13 & .598 & 1.662 & 85.515 & & \\
\hline 14 & .547 & 1.520 & 87.036 & & \\
\hline 15 & .533 & 1.480 & 88.516 & & \\
\hline 16 & .467 & 1.297 & 89.813 & & \\
\hline 17 & .441 & 1.225 & 91.038 & & \\
\hline 18 & .411 & 1.142 & 92.181 & & \\
\hline 19 & .375 & 1.042 & 93.222 & & \\
\hline 20 & .300 & .833 & 94.055 & & \\
\hline 21 & .271 & .754 & 94.809 & & \\
\hline 22 & .259 & .720 & 95.529 & & \\
\hline 23 & .248 & .688 & 96.217 & & \\
\hline 24 & .201 & .557 & 96.775 & & \\
\hline 25 & .191 & .531 & 97.306 & & \\
\hline 26 & .161 & .448 & 97.753 & & \\
\hline 27 & .142 & .394 & 98.147 & & \\
\hline 28 & .128 & .354 & 98.502 & & \\
\hline 29 & .113 & .314 & 98.816 & & \\
\hline 30 & .105 & .292 & 99.108 & & \\
\hline 31 & .085 & .236 & 99.344 & & \\
\hline 32 & .073 & .201 & 99.546 & & \\
\hline 33 & .058 & .161 & 99.706 & & \\
\hline 34 & .053 & .147 & 99.853 & & \\
\hline 35 & .031 & .086 & 99.939 & & \\
\hline 36 & .022 & .061 & 100.000 & & \\
\hline
\end{tabular}

Finally,From Table3.6 we see 8 factors are extracted, and these 8 factors have a good corresponding relationship with the item items. The cumulative variance explanation rate was $75.233 \%$. 


\section{Conclusion}

\begin{tabular}{|c|c|c|c|c|c|c|c|}
\hline \multicolumn{8}{|c|}{ Correlations } \\
\hline & & $\begin{array}{l}\text { enterprise } \\
\text { strength-1 }\end{array}$ & $\begin{array}{l}\text { enterprise } \\
\text { strength-2 }\end{array}$ & $\begin{array}{l}\text { enterprise } \\
\text { strength-3 }\end{array}$ & $\begin{array}{l}\text { enterprise } \\
\text { strength-4 }\end{array}$ & $\begin{array}{l}\text { overall the } \\
\text { latitude-1 }\end{array}$ & $\begin{array}{l}\text { overall the } \\
\text { latitude-2 }\end{array}$ \\
\hline \multirow[t]{3}{*}{ enterprise strength-1 } & Pearson Correlation & 1 & $.693^{* *}$ & $.770^{* *}$ & $.253^{*}$ & $.677^{* *}$ & $.636^{* *}$ \\
\hline & Sig. (2-tailed) & & .000 & .000 & .023 & .000 & .000 \\
\hline & $\mathrm{N}$ & 80 & 80 & 80 & 80 & 80 & 80 \\
\hline \multirow[t]{3}{*}{ enterprise strength-2 } & Pearson Correlation & $.693^{* *}$ & 1 & $.599^{* *}$ & .180 & $.567^{* *}$ & $.403^{* * *}$ \\
\hline & Sig. (2-tailed) & .000 & & .000 & .110 & .000 & .000 \\
\hline & $\mathrm{N}$ & 80 & 80 & 80 & 80 & 80 & 80 \\
\hline \multirow[t]{3}{*}{ enterprise strength-3 } & Pearson Correlation & $.770^{* *}$ & $.599^{* *}$ & 1 & $.253^{*}$ & $.634^{* *}$ & $.568^{* *}$ \\
\hline & Sig. (2-tailed) & .000 & .000 & & .024 & .000 & .000 \\
\hline & $\mathrm{N}$ & 80 & 80 & 80 & 80 & 80 & 80 \\
\hline \multirow[t]{3}{*}{ enterprise strength-4 } & Pearson Correlation & $.253^{*}$ & .180 & $.253^{*}$ & 1 & $.387^{* *}$ & $.500^{* *}$ \\
\hline & Sig. (2-tailed) & .023 & .110 & .024 & & .000 & .000 \\
\hline & $\mathrm{N}$ & 80 & 80 & 80 & 80 & 80 & 80 \\
\hline \multirow[t]{3}{*}{ overall the latitude-1 } & Pearson Correlation & $.677^{* \star}$ & $.567^{* *}$ & $.634^{* *}$ & $.387^{* *}$ & 1 & $.725^{* *}$ \\
\hline & Sig. (2-tailed) & .000 & .000 & .000 & .000 & & .000 \\
\hline & $\mathrm{N}$ & 80 & 80 & 80 & 80 & 80 & 80 \\
\hline \multirow[t]{3}{*}{ overall the latitude- 2} & Pearson Correlation & $.636^{\star \star *}$ & $.403^{\star *}$ & $.568^{* *}$ & $.500^{* *}$ & $.725^{\star *}$ & 1 \\
\hline & Sig. (2-tailed) & .000 & .000 & .000 & .000 & .000 & \\
\hline & $\mathrm{N}$ & 80 & 80 & 80 & 80 & 80 & 80 \\
\hline
\end{tabular}

Table 3.7

This research focuses on the relationship between corporate strength and brand employers. Therefore, four item data in the latitude of corporate strength and the total latitude of brand employers are selected for correlation analysis. The independent variable is corporate strength. The specific items are: I think the development prospects of the company, I think the influence of the company, I think the leadership image of the company, I think the layoffs during the epidemic period are the evaluation of the company's development. The dependent variable is the overall employer brand evaluation: I am willing to stay in the company and I am proud of working in this company. Compared with other companies, I think this company is a better place to work.

From Table3.7,Correlation analysis shows that the Pearson correlation coefficients for the independent variables and dependent variables of the four latitudes of corporate strength, which I am willing to stay in and proud of working in this company are: $0.677,0.567,0.634$, 0.387. The Pearson correlation coefficients with the dependent variables I think the company is a better workplace are: $0.636,0.403,0.568,0.500$. Therefore, there is a positive correlation between independent variables and dependent variables under the latitude of firm strength. Specific analysis: The independent variable under the latitude of the company's strength: I think the correlation coefficient between the layoffs during the epidemic and the dependent variable I am willing to stay in the company and proud of working in the company is 0.387 , and the dependent variable I think the company The correlation coefficient of a better workplace is 0.500 , indicating a significant correlation between the two.

Therefore, the study hypothesis is established. layoffs have a positive impact on the employer branding. When employees believe that layoffs during the epidemic are not good for the company's development, and it is not good for the company's employer branding.

\section{Research Contribution}

The research on employer branding is mainly between employers and employees. At present, the research on employer branding mainly focuses on the construction and maintenance of employer branding. There is a lack of empirical research on the factors influencing employer branding. This study enriches the relevant research theory. In addition, most of the research 
on human resource management focuses on the employee research in the modules of human resource planning, recruitment, training, performance, salary and labor relations, and the research on employer brand is not enough. This study enriches the empirical research on employer brand. In addition, under the influence of the COVID-19, what is the impact of enterprise layoffs on the internal employer branding? Lack of relevant empirical research content, this study uses real employee data to analyze the real reflection of employees on employer layoffs.

\section{Discussion}

\section{layoffs During the Epidemic are not the only way}

Having a job is the guarantee of survival and livelihood. In the face of emergencies such as the epidemic, employees tend to stay in the company, so that they can have a sense of security and basic living security. How an enterprise maintains its own employer brand is not the only way to lay off employees, because talent is the most important wealth and resource of an enterprise. If the loss of talent is serious, the employer brand will be damaged and it will affect the operation and development of the enterprise. You can take turns to take vacations and pay basic salary to retain employees and talents.

\section{Employer Brand Building is a Long-Term Process}

Employer brand building is not carried out in the short term. On the contrary, it requires longterm construction. This requires the joint efforts of employees and the management of the company, rather than the responsibility and obligation of one of them. Companies can retain their talents by optimizing performance and salary models, and innovating management methods.

\section{Enterprises need to Establish Emergency Response Mechanisms to Maintain Employer Brand}

Under the influence of the epidemic, it also reflects that many companies have insufficient ability to respond to emergencies, slow response, single response measures and other human resource management problems. The human resource management department of enterprises needs to establish a complete scientific mechanism for responding to emergencies. , Allowing companies to retain talents and maintain their employer brand in the face of emergencies.

Limitations of this Study and Future Recommendations: Because of the limited sample size, the samples sampled in this study cannot represent all the matrices studied, and there are certain deviations. In future studies, the sample size needs to be further expanded. The crosssectional data used does not collect time series data, which has certain limitations. In the future, panel data should be used for further analysis and research.

\section{References}

Agarwal, S., \& Sharma, R. (2021). Employer Branding for Competitive Advantage: Models and Implementation Strategies.CRC Press.

Nasser, F., \& Ayman, M. (2020). The Influence of Employer Branding on Employer Attractiveness and Employee Engagement and Retention: Ten Years of Literature. 11(4), 48-69. 
Adrian, C., \& Oliver, R. (2020). Attracting future civil servants with public values? An experimental study on employer branding. International Journal of Advertising. 23(5), 677-695.

Anjali, l., \& Jagathy, B. (2020). Employer Branding: A Decisive Means of Employee Relationship Management. International Journal of Business and Society.10(3), 23-40.

Chawla, P. (2020). Impact of Employer Branding on Employee Engagement in BPO Sector in India With the Mediating Effect of Person-Organisation Fit. International Journal of Business Innovation and Research. 11(3), 59-73.

Prabhjot, K., \& Sanjeev, K. (2020). Employer Branding and Organisational Citizenship Behaviour: The Mediating Role of Job Satisfaction. International Journal of Communication. 16(2), 122-131.

Doubell, M. (2020). The influence of employer branding and employees' personal branding on corporate branding and corporate reputation: African Journal of Business and Economic Research.15(2).

Antonios, K., \& Alexios, T. (2020). Employer Branding Implementation and Human Resource Management in Greek Telecommunication Industry. International Journal of Management and Business Research. 10(1)

Bejtkovský, J., \& Narcis, C. (2020). The Employer Branding Creation and HR Marketing in Selected Healthcare

Service Providers. International Journal of Business and Society. 15(1), 95-108.

Zhu, G. (2008). Evaluation and Management of Employer Branding. International Journal of Management Education. China Labor and Social Security Press. 